\title{
Research on the Construction and Optimization of China's Regional Credit System
}

\author{
Hangmin Li \\ Guanghua Law School \\ Zhejiang University \\ Hangzhou, China \\ lihangmin0325@gmail.com
}

\begin{abstract}
Regional credit system is one of the general requirements in the national economic and social construction, and it is proposed in the Planning Framework for the Construction of Social Credit System (2014-2020) by China's state council. To construct and optimize China's regional credit system, this paper presented three general modes of regional credit system based on the experience of Shanghai, Shenzhen and Zhejiang. According to the comparison of different modes, this paper suggests the effective approach to construct the regional credit system in China is combining the government leading and market participation. The measures to optimize the construction of credit system at the regional level include optimizing the local public credit database by widening the channels of information collection and use, further cultivating and standardizing the local credit service industry, and establishing the mechanism of credit supervision and dishonesty punishment.
\end{abstract}

Keywords—regional credit system; mixed mode; regional public credit database; credit service industry; dishonesty punishment

\section{INTRODUCTION}

In March 15, 2013 Regulations of the People's Republic of China on Administration of Credit Information Industry came into effect, which is China's first ordinance to make operational provisions for the credit information collection and use and the main responsibilities and obligations. The provisions cover credit agencies, providing and using of credit information, and the punishment for bad and inaccurate credit information record and also give the outline of the provisions toward China's financial credit database. This ordinance mentions enterprises' credit and natural person's credit, and also tells the differences in credit information collection and use of these two credits with different types of subjects. Although the implementation of the regulations has played a certain role in guiding norms and promoting development of China's credit industry, consciousness of the whole society on credit information collection and use is not strong because China's credit information industry started late. The credit market has a long way to go, especially because of the economic marginal effect of the cost and use of credit information collection [1], the collection and use of current national credit information is more difficult and costly, resulting in a more economical situation of the credit information collection and use in regions. To comprehensively consider what is mentioned, the ordinance stipulates in Article 4 of the General Regulations that while the People's Bank and its dispatched institutions shall supervise and administer the credit bureaus, the local people's governments shall be required to push forward the construction of the social credit system and cultivate credit market according to the law.

\section{AN ANALysis of THE GENERAL MODES OF CURRENT REGIONAL CREDIT SYSTEM}

Although in the laws and regulations, Regulations of the People's Republic of China on Administration of Credit Information Industry for the requirements of construction of regional credit system appeared late, in fact, China's regional credit system construction has long been carried out, and the economically developed regions have made certain experience. The local governments are more advanced than the national legislation in construction of the credit system, especially the use of credit system. By observing credit systems of Shanghai, Zhejiang, Shenzhen and other regions, we can sum up the general model of local credit construction.

\section{A. Government-Leading mode}

China's credit information and data are mainly distributed in banks, insurance companies and other financial institutions and other government departments. It can be said that the government is the largest credit information owner. From the perspective the efficiency of information extraction, effectiveness of information and cost, it is the most economical for government to lead credit information collection and database construction. As China's earliest start of regional credit system, Shanghai has obvious government-leading characteristic in the credit system construction. Shanghai Credit Co., Ltd., Shanghai's first and largest credit information agency is set by the Shanghai government and China's central bank. With the advantages of government leading, Shanghai Credit Co., Ltd. got support from the People's Bank of China and acquired consumer credit information of 15 Chinese banks. In the widen scope of credit information collection, the company also got support from government departments and public institutions. The information it collected including the tax, customs, utilities and other payment records. During the construction of the credit project in Shanghai Credit Co., Ltd., the Shanghai government provided RMB 50 million to the project with a 5-year interest-free loan in the form of financial borrowing [2]. In the business of credit information products, currently product demand of Credit Co., Ltd. is mainly created by the government. Similar to Shanghai, with the support of 
the People's Bank of China, Shenzhen has set up Shenzhen Credit Rating Co., Ltd. ${ }^{1}$ to operate Shenzhen's personal credit information system. Before the promulgation of Regulations of the People's Republic of China on Administration of Credit Information Industry in 2013, due to the lack of corresponding laws and regulations, it is difficult for local governments to grasp the balance of information disclosure and safeguarding the legitimate rights and interests of the main body. In this case, Measures on Shenzhen Personal Credit Information and Credit Rating implemented by the Shenzhen government in 2002, which makes the guidelines for the subject, behavior, and legal responsibility of credit involved in the regional personal credit information, and became the first personal credit legislation in China.

In the construction of regional credit system, a credit company established by the local government or the central bank is a third-party credit agency, and in essence, plays the role of local personal and corporate credit information database. Credit information collection of this type of database is from a number of government departments, financial institutions and public institutions, so information sources are official; and since few of it is collected in the market, it is also known as the joint credit platform in some areas. In other areas where credit system construction is relatively advanced in our country, local credit information databases have also been selected in the basic stage of credit construction such as the establishment of Zhejiang Personal and Corporate Joint Credit Platform. The platform is a website with personal and business-related credit information collected by Zhejiang Credit Office in the administrative process of local government, and information services of this platform do not charge fees. Shandong, Hubei, Hunan, Anhui and other provinces and cities have taken such a mode too.

\section{B. Market-Participation Mode}

After the amendment of China's Securities Law in 2005, the credit rating agencies is included in the scope of securities trading services institutions and the conditions for the establishment, approval procedures and business rules of credit rating agencies are formulated by Securities Supervision and Administration Institution under the State Council, so the credit rating industry in the domestic capital market is relatively standardized and institutionalized. In the construction of the regional credit system, although the construction of the basic database of the credit information takes a government-leading approach, in recent years credit service organizations represented by credit rating agencies have gradually increased in the credit market, and the main mode of supervision of credit services organizations is filing system. Taking Zhejiang Province as an example, the credit service agencies filed to government have reached $38^{(2)}$. The services provided by the local credit service agencies mainly include credit collection service, debt collection, credit rating and credit management.

(1). This company changed its name to Shenzhen Pengyuan Credit Rating Co., Ltd. in July 1998. And in November 1998, State Administration for Industry and Commerce accepted its name change.

(2). Data sources: "List of Yangtze River Delta Region Recorded Credit Service Institutions - Zhejiang Province”,

http://www.zjcredit.gov.cn/html/xyfw/xyfw5.htm, last access time: 6 October, 2016.
Unlike the credit rating in the securities industry, some local private credit service organizations contain general business and enterprises in the credit rating. Before the implementation of Regulations of the People's Republic of China on Administration of Credit Information Industry in 2013 to establish general rules for the management of credit service agencies, local credit service institutions lacked corresponding national regulatory and management systems, so some local authorities issued corresponding regulatory documents, such as Interim Measures for the Management of Credit Services in Zhejiang Province. In the regulation of credit collecting behavior of credit service agencies, currently the legislation has made different provisions on the collection and the provision of personal credit information and enterprise credit information, and the collection and use of personal credit information is more cautious than the enterprise credit information and pays attention to the protection of personal privacy. But because of the social nature of enterprises, as long as it does not infringe business secrets, the credit information is generally shared [3].

\section{Mixed Mode}

Credit information databases operated by local joint credit platforms or local credit information agencies reflect the characteristics of public credit agencies, and at the same time the growth of local credit service agencies represents the rise of private credit bureaus. It is generally believed that public credit agencies and private credit agencies are not substitutes for each other, but complementary organizations to improve the efficiency of credit information application [4]. The World Bank's policy recommendations for countries with a credit system suggest that public credit bureaus are not a substitute for private credit bureaus but a complement to private credit bureaus [5]. However, the construction of regional credit system in our country is still dominated by the credit services of public credit agencies, while the market share of private credit service institutions is not large. At present, the construction path of the typical regional credit system is based on joint credit platforms and credit companies established or supported by the local government or the central bank; private credit service companies, which take extensive record-filing management ${ }^{(3)}$ are complement in the credit service market.

\section{ENLIGHTENMENT OF CONSTRUCTION OF REGIONAL CREDIT SYSTEM}

The construction of regional government-leading credit system has played a great role in the credit information collection and credit network construction. Therefore, the local credit information database has been continuously improved on the basis of the original situation to facilitate the provision of more services especially in the development of mixed credit and the control of local financial risk, which should be the trend of local credit construction. Particularly in the field of credit, how to coordinate the relationship between the central and local credit information system and improve the efficiency of resource use is an important issue under the system of the central credit registration system, namely the national credit information database and the local credit information database.

(3). After the implementation of Regulations of the People's Republic of China on Administration of Credit Information Industry, it turned the management of credit institutions into a more stringent approval system. 
In the area of informal financial prosperity and development, it has provided a way to solve this contradiction. Local credit information collection system provides useful supplement for the credit information collection of the central bank.

In addition, the coordination of the relationship between the local government's public credit information database and private credit service organizations is also important. Due to the government support and low cost of information collection, the public credit information database should protect private credit service organizations from being forced out of the market. In some places, such as Zhejiang and Jiangsu, local credit information databases only provide the credit information generated in the administrative affairs and court decisions, and adopt a simpler credit rating for the credit evaluation. However, a more detailed credit report, or a credit rating in a particular area, such as a credit rating for a tendering exercise, is done by a private credit service agency.

\section{CONSTRUCTION AND OPTIMIZATION OF REGIONAL CREDIT SYSTEM}

The development of credit system in Europe and the United States mostly relies on the credit market. Businesses and individuals play a decisive role, on the basis of which government intervenes and makes credit laws to guide the norm [6]. However, the construction of China's regional credit system is based on the government leading, in which the construction of credit database and the demand for credit information products are set up and provided by the government. Due to the unbalanced regional economic development and the different demands for the construction of credit system, the local governments of different provinces and municipalities in China have different start-up time and effect of building regional credit system. The more developed eastern regions started the credit system construction earlier, and the credit market is also more mature. Combining the existing achievements and experiences, the construction of regional credit system in China can be optimized on specific measures: further develop the government-dominated advantages, accelerate the development and maturity of credit market, integrate the government-leading and market participation mechanism, and accelerate the growth of regional credit system.

\section{A. Broadening the Way of Acquiring and Using Credit Information for Local Public Credit Database}

The local public credit database is the core content and basic platform for the construction of local government credit service. The personal and enterprise credit information is also an important source of credit information for the credit service agencies, sharing the joint credit platform for government departments, enhancing the comprehensive supervision capability, and providing tremendous help for the improvement of social and public service quality.

In the aspect of credit information collection, the public credit information database set up by the local government plays a positive role in the process of promoting the integration of the credit system among the finance, industry and commerce, and taxation and handling issues on the monopoly of credit information industry in dealing with the construction of the credit system and the sharing of credit information. With the fact that the government information is continuously transparent, the construction of local public credit database, and the situation of the lack of deep cooperation in inter-governmental credit information have been gradually improved.

However, the lack of the exchanges of credit information between financial system and non-financial system is still a problem in data collection of local credit information database. Taking the local experience as a reference, the local credit information database with the background of bank shares and the central bank supports has the advantage in the collection of financial credit information. The construction of the credit system depends on the sharing of credit information. The credit information sharing between the local credit information database and the financial credit information database still needs to be advanced.

\section{B. Standardizing and Cultivating the Regionl Credit Service Industry}

As an important component of the credit market, credit service institutions play an important role in building a sound social credit system. Credit service agencies can release effective credit demand and promote the healthy development of the economy [7]. However, due to the profitability of the market, compared with public credit database led by the government, the credit service agencies prefer to go after efficiency and show a wide range of features in the collection of information and provision of services, so the relevant legal environment and the level of law enforcement are required highly, otherwise there will be possible abuse of credit information resources and infringement of consumer privacy and other contradictions and problems [8]. In addition, credit service agencies aim at solving problems in the information asymmetry in credit transactions. Although there is a certain degree of information sharing among credit service institutions, there is also information asymmetry, leading to the differences of credit reports provided by different credit service institutions.

In the United States, where the credit market is well developed and is dominated by private credit bureaus, credit intermediary agencies engaged in such businesses as credit information, credit rating, account collection and credit management not only are subject to the Fair Credit Reporting Act, Fair Debt Collection Practices Act and other legal norms, but also accept self-regulatory supervision of the credit industry associations, to prevent defects that operation alone of credit service agencies may lead to. At present, China has not set up sound laws and regulations system for all kinds of credit service institutions, resulting in that responsibilities and obligations in the establishment, operation, supervision and corresponding rights of credit service institutions have not been clearly defined. In order to supervise credit service institutions effectively and promote the development of the credit market, the relevant legal support is needed. According to the vacancy of national legislation, the local government can formulate corresponding normative documents in the process of the credit system construction, and regulate the credit service institutions, 
which have not covered by the national legislation, such as debt collection companies.

Since the construction of regional credit system in our country mainly adopts the government-leading mode, in the provision of credit service, the government breaks the certain credit market demand by establishing the public credit information database. In order to prevent the public credit database from excessively squeezing the living space of private credit service institutions, reference to the German experience of public credit system model leading, construction of regional credit system can set a certain amount or important level of indicators in local public credit information database, and prevent the asymmetry of credit market information through the regular update and supervision of public credit database. Or referring to the experience of joint credit platform construction in Zhejiang Province, it only provides relatively simple star-level credit information in credit rating service, and the more complex and detailed credit rating is completed by the credit service agencies, so that the concept of the interaction between market mechanism and the government's macro-control has been reflected in the construction of credit services industry [9].

\section{Building Credit Supervision and Dishonesty Punishment Mechanism}

Market players are "rational people” and "economic man”, which all acts they do in the market are to maximize their interests. If trustworthiness can bring benefits, and dishonesty can bring losses, they will not hesitate to choose trustworthiness, and vice versa [10]. But the way to make the trustee to keep faith and to punish those who fail to keep faith can't be solved by taking the credit reports back, but need to construct dishonesty punishment mechanism. Because of the fact that our legislation only regards "honesty and trustworthiness" as a principled clauses, we do not have the corresponding responsibility mechanism for this clause, and the act of dishonesty is only constrained by the social morality, resulting in meaninglessness of this clause to some extent. In addition, the establishment of dishonesty punishment system can also produce the binding force and deterrence to people with bad credit records through various types credit products of credit service institutions, and the spread of negative information and behavior restrictions within a certain period of people with bad credit records, so as to make people with bad credit records to pay cost of dishonesty because of their behaviors of dishonesty. Although some scholars questioned the legitimacy of dishonesty punishment mechanism and they thought that the relationship between credit and acceptance is essentially equal to the relationship between creditors and debtors established by equal parties and there is no punishment among equal parties [11]. But since the relationship between credit and acceptance relates to public interests and social interests, the dishonest should be responsible for this issue in order to safeguard the fairness of the credit market.

The construction of credit supervision and dishonesty punishment system includes the investigation and verification, hearing, transparency and appeal of dishonesty behavior. By punishing those who fail to keep faith, dishonest enterprises and individuals will be excluded from the local credit market.
From the specific measures, in the process of building credit system, the local government can strengthen financial cooperation among the financial industry to jointly punish people or companies with evasion of financial debt, actively use the local credit information database, and publish name lists of personal and enterprises with bad credit records regularly. In order to ensure the fairness of the "blacklist" system, local governments should establish the corresponding complaint system for dishonesty punishment to give right of appeal to the enterprises and individuals who are recorded in the "blacklist". In addition, encourage and support enterprises with good credit records in the economic construction, thus forming a positive incentive mechanism with preferential policy and social environment to honest and trustworthy enterprises and consumers.

\section{CONCLUSION}

According to the current experience of regional credit system construction, government leading will still be the mainstream driving force in the next period of time. However, with the development of credit service institutions and credit market, the demand and application of personal and corporate credit information products will be cultivated and mature gradually. The growth mechanism of credit system led by the government and market will tend to equilibrium. Therefor this paper suggests that combining the government leading and market participation would be an effective approach to construct China's regional credit system. With suggested approach, specific measures should be took to optimize the construction of regional credit system, including broadening the way of acquiring and using credit information for local public credit database, standardizing and cultivating the regional credit service industry, and building credit supervision and dishonesty punishment mechanism.

\section{REFERENCES}

[1] L.C. Xiao, "Study on Model of Local Credit System Construction," Research on Economic Development, vol. 2, 2012, pp. 7-11. (In Chinese)

[2] Z.L. Zhao, F. Ding, "Problems and Enlightenment of Model of Social Credit System Construction,” Wei Shi, vol. 10, 2007, pp. 70-73. (In Chinese)

[3] S.Q. Ye, Research on Legal Principle and Practice of Credit, 1st ed., Beijing: Law Press, 2010, p. 110. (In Chinese)

[4] D.W Hu, J. Du, Research on the Legal System of Credit, 1st ed., Beijing: Law Press, 2012, p. 211. (In Chinese)

[5] M. Miller, "Credit reporting systems around the globe: the state of the art in public and private credit registries," World Bank, Presented at the Second Consumer Credit Reporting World Conference, San Francisco, California, October, 2000.

[6] D.X. Yuan, "Research on the Mechanism and Stage of Regional Credit Growth,” Finance and Trade Economics, vol. 10, 2010, pp.120-127. (In Chinese)

[7] Y.S. Lou, "To Guide and Regulate the Development of Credit Service Agencies,” Zhejiang Economy, vol. 17, 2012, pp.32-33. (In Chinese)

[8] J. Yao, The Legal Regulation of Personal Financial Credit, 1st ed., Beijing: Social Science Literature Press, 2012, p.101. (In Chinese)

[9] M.Z. Xu, "the Coupling of Market Mechanism and Macroeconomic Regulation,” Jurists Review, vol. 2, 1996, pp.45-48. (In Chinese) 
[10] Y.Y. Zhao, "The Legal System Support of Financial Credit - An Interpretation from the Angle of Law and Economics," Economy and Legal System, vol. 9, 2008, PP.226-228. (In Chinese)

[11] L.Y. Li, Research on Consumer Credit Law, 1st ed., 2000, Beijing: Law Press, p.3. (In Chinese) 